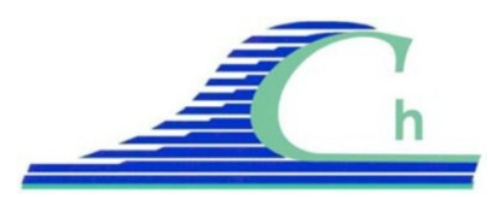

XII ${ }^{\text {ìmes }}$ Journées Nationales Génie Côtier - Génie Civil

Cherbourg, 12-14 juin 2012

DOI:10.5150/jngcgc.2012.078-E（C) Editions Paralia CFL

disponible en ligne - http://www.paralia.fr - available online

\title{
Misurata free zone port development can serve south of Libya and neighbour landlocked countries
}

\author{
Fathi M. ESAHERI ${ }^{1}$
}

1. B.Sc Civil Eng. M.sc Maritime Eng. Port consultant- Part-time lecturer, at The Libyan University/Tripoli. Libya.

fathi_eseheri@yahoo.co.uk

\begin{abstract}
:
Misurata commercial seaport is one of the important and distinguished ports on the southern coast of the Mediterranean Sea, located $200 \mathrm{~km}$ east of Tripoli city, and $12 \mathrm{~km}$ east of Misurata ; the third largest city in Libya. This port belongs to Misurata Free Zone Co. (MFZ).There is another port eastward of the commercial port and not faraway. The later belongs to the Libyan Iron and Steel Company (LISCO). The aim of this paper is to discuss, from an engineering point of view, the expansion of the new proposed port in the territory between the two ports. Another location for such development will be proposed as alternative. The objective of this paper is also to draw the attention to the close link between such project and the extent of the Libyan net of roads (North-South), and roads in the landlocked countries. Highlights will be focused on how careful integration between land transport and port infrastructures could make global trade transport from the Mediterranean to sub-Saharan landlocked countries south of Libya possible (figure 1). The available net of roads constructed or under consideration, planned railway net, and low land transport costs due to low prices of oil products in Libya are considered. Low goods cost, and increase in employment chances are factors among such economic outcome. Long term policy for global opportunities investment by private or public sector is of interest in this paper too, bearing in mind that the volume of trade through the Mediterranean is nearly 30\% of global trade, and $40 \%$ of Africa's trade with European Union countries (UNCTAD, 2009).
\end{abstract}

\section{Keywords:}

Container - Shipping-free zone - Misurata - Libya - Mediterranean

\section{Introduction}

Construction works for phase one of the existing commercial port started in 1973, and port operation began in 1978 with a capacity of one million tons per year. Other phases of development were followed to reach the present capacity of 6 million tons per year. LISCO owns a factory of liquid steel of 1,324,000 tons production capacity per year. LISCO port's capacity is 2 million tons per year, and can accommodate bulk orecarriers up-to 90,000 D.W.T. 
The interesting point is that the two ports are only 3-4 kilometres apart This territory is the location of two schemes (layouts) of the proposed expansion of the existing commercial port to achieve a yearly capacity of 10 million tons; subject of this paper. Focus will be on the expansion of the container terminals.

It appears that the two existing ports are protected from waves, currents and consequently protected from excessive waves or siltation inside the port basins which allow both of them to be operating most of the year; this might be the reason why two independent consultants selected two locations close to each other. Excellent hinterlands and reasonable water depths are evident, Fig. (2).



Figure 1. General layout of road net between Libya-Niger-Chad.

Brief description of existing commercial port:

Quays Length: 4150 metres of average 8 to $13 \mathrm{~m}$ depth

Grain Silos: 40,000 tons capacity

Paved Storage Area: 67,500 $\mathrm{m}^{2}$ roofed \& 290 hectares open.

Shipping and cargo statistics are shown in table 1.

Table 1. Shipping and handling statistics (2006-2010).(MFZ, website)

\begin{tabular}{llllll}
\hline Year & $\begin{array}{l}\text { Incoming } \\
\text { Ships }\end{array}$ & $\begin{array}{l}\text { Total No. of containers } \\
\text { (TEU'S) unloaded }\end{array}$ & $\begin{array}{l}\text { Total No of containers } \\
\text { (TEU'S) loaded }\end{array}$ & $\begin{array}{l}\text { Total cargo } \\
\text { (tons) }\end{array}$ & $\begin{array}{l}\text { Growth } \\
\text { \%age }\end{array}$ \\
\hline 2006 & 1042 & 63432 & 64637 & $1,903,141$ & $35 \%$ \\
2007 & 1160 & 64712 & 62118 & $2,514,459$ & $32 \%$ \\
2008 & 1253 & 99096 & 94857 & $2,527,342$ & $1 \%$ \\
2009 & 2031 & 133727 & 125592 & $3,571,851$ & $29 \%$ \\
2010 & 1805 & 130770 & 125100 & $3,554,792$ & $-.05 \%$ \\
\hline
\end{tabular}


Brief outlines of the proposed new port:

Scheme A (Fig.3)

- Phase 1: Construction of breakwater of $3435 \mathrm{~m}$ length, between the two ports to give a port basin of 600 hectares of water area, and new container berth of $2250 \mathrm{~m}$ length and 400 m width with a depth of -18 m CD, to accommodate 5 Post Super Panama Container Vessels. Paved Storage area of 65 hectares. Navigation channel and port entrance to be dredged down to -20m CD.

- Phase 2: Construction of additional container berth with a length of $1750 \mathrm{~m}$ and $584 \mathrm{~m}$ width. The depth is $-18 \mathrm{~m}$ CD, plus an additional paved storage area of 60 ha.

Scheme B (Fig.4)

- Phase1: Extension of the existing north breakwater of the commercial port by $2300 \mathrm{~m}$. Construction of an offshore breakwater of $1800 \mathrm{~m}$. Construction of two finger piers as container berth with total length of $3600 \mathrm{~m}$ with a depth of-18 m CD.

- Phase 2:Construction a breakwater between the off-shore and leg of the main breakwater of the LISCO port with a $500 \mathrm{~m}$ approximate length. Construction of an additional $2792 \mathrm{~m}$ container berth with the same depth.

\section{Analysis of the impacts of the new port on the two existing ports:}

\subsection{Navigation and shipping aspects}

LISCO port will not be affected by implementing either of the two schemes (A \& B), at least from a commercial point of view, but hydraulic effects inside the harbour basin and effect on navigation through the port channel should be considered during the model studies, to make sure that adverse effects regarding navigation occurs, berthing or siltation to LISCO port. Provision for future deepening of the outer navigation channel, entrance and turning circle to $-22 \mathrm{~m}$ to cope with possible growth of trade and future trends in container vessel size should be considered.

Both schemes (A \& B) are expected to have direct effect on wave penetration inside the port basin of the existing commercial port. The degree of protection will be improved by scheme A, and reduced by scheme B due to expected reflection of new breakwater. It is worthwhile, to study such matters in details, in addition to navigational aspects and sedimentation processes when performing model testing for this project

Carrying-out site investigation for another alternative site eastside of LISCO port and convenient for MFZ compound, might get some advantages in minimizing direct and indirect effects on both two existing ports from the hydraulic and navigational points of view. Construction of the new port in a new alternative location could be reflected positively on time and cost of construction and avoid problems that will arise during construction, such as siltation of fine materials of the rubble-mound breakwater components and interruption of navigation or cargo handling on east breakwater of the commercial port. 
Thème 4-Ouvrages portuaires et offshore

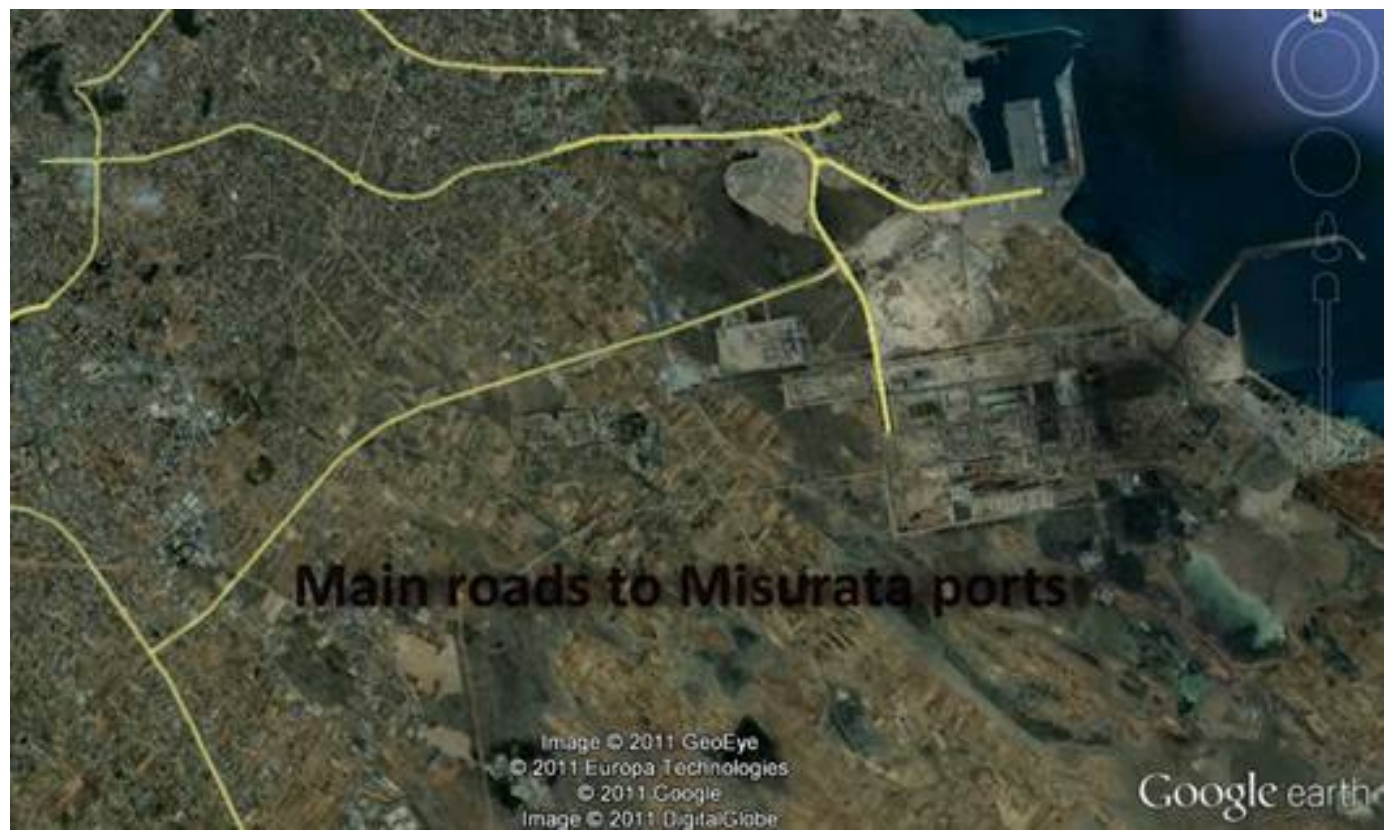

Figure 2. General satellite view of the location of the two ports in Misurata.

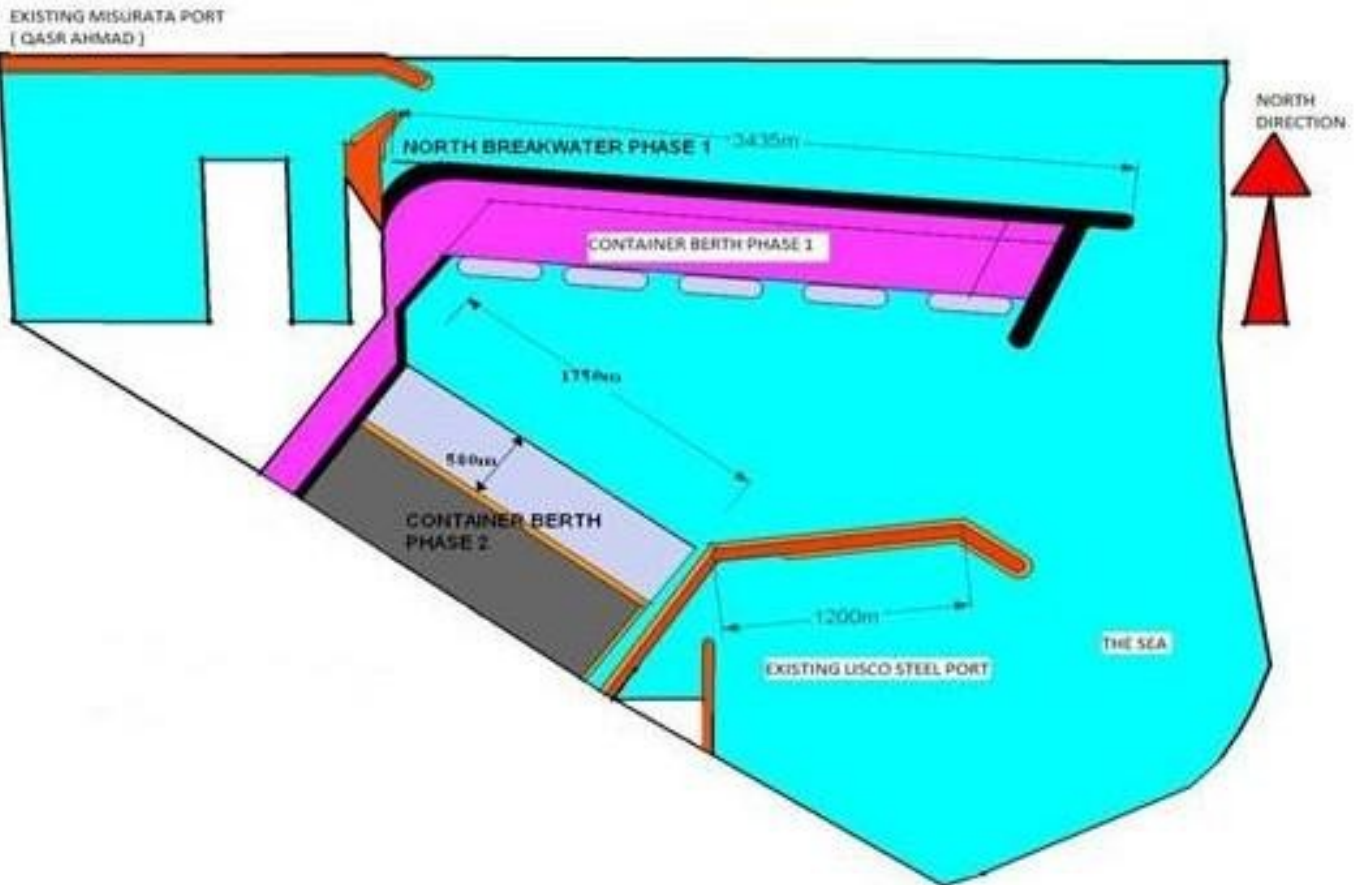

Figure 3. Overall Proposed New Port Layout Scheme A (MFZ, brochures). 


\section{XII ${ }^{\text {èmes }}$ Journées Nationales Génie Côtier - Génie Civil \\ Cherbourg, 12-14 juin 2012}

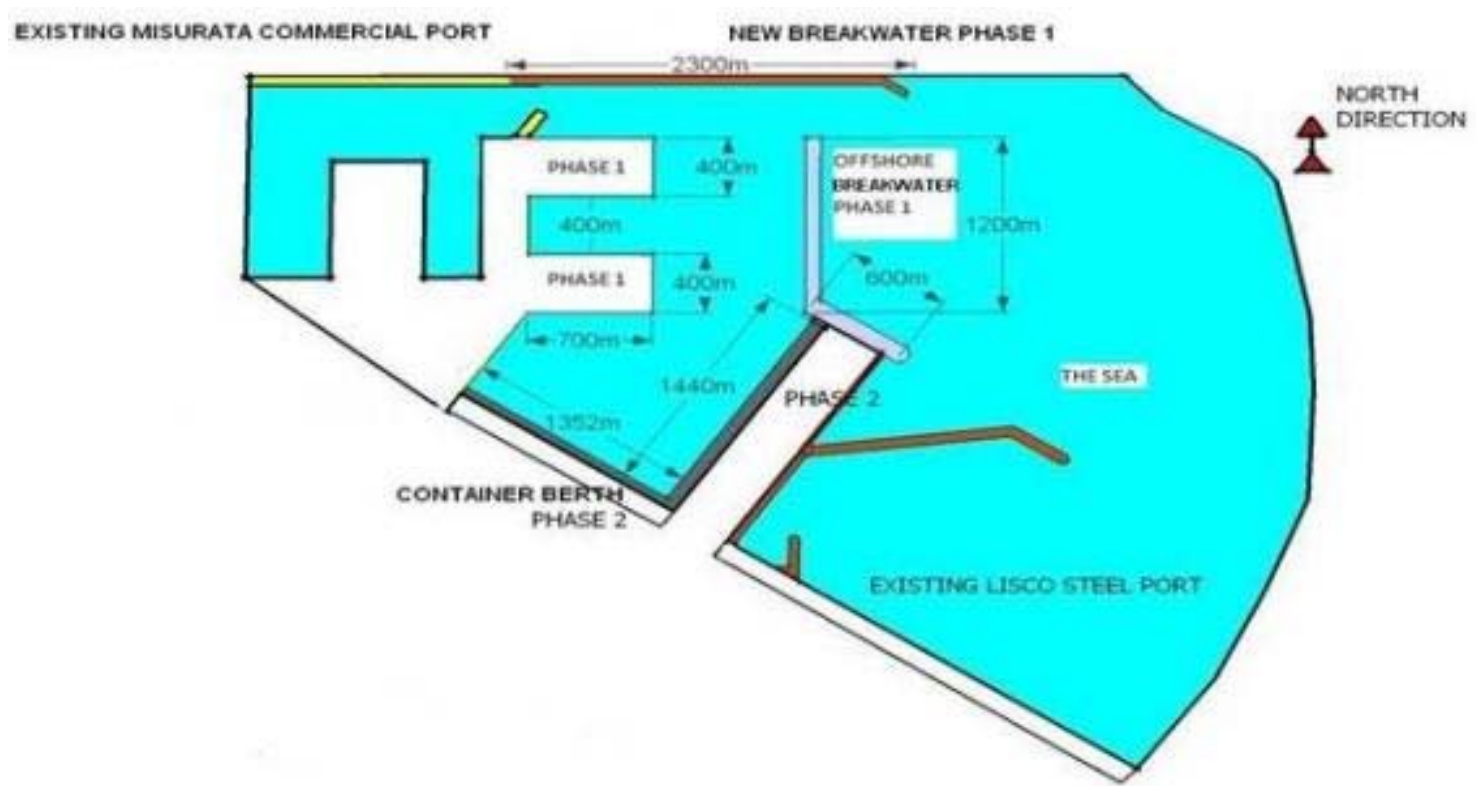

Figure 4. Overall Proposed New Port Layout Scheme B (MFZ, brochures).

\subsection{Land transport aspect (trucks haulage operation)}

There is a linkage between the cost of transport and trade volumes, with higher costs constraining the flow of goods. In a study by The World Bank, in 1999, (WORLD BANK, 2001) a general ratio of a $10 \%$ rise in transport costs resulted in $20 \%$ volume reduction. In the same study, the comparative impact of changes in the proportion of sea-versus land transit upon the overall transport cost was highlighted. Using distance as a proxy for transport costs, it was found that an additional 1,000 km of sea transport raised the freight element by US $\$ 190$ for medium shipment. In comparison, similar addition in land distance raised it by US\$1,380.

For landlocked countries, land based transport costs were found to increase by US $\$ 2,170$ reflecting a 50\% increase in average total cost. The reasons underlying this Scale factor of change largely relate to comparative economy of scale transportation unit, the ship versus the truck or rail load, in addition to cross borders delay, infrastructure deficiency, security and insurance issues and other problems.

It is possible to shift the mode of trade transport to and from the landlocked countries to the Mediterranean through the M.F.Z. This means minimization of the sea transport leg, and relatively reduction in land distance for hauliers' transport.

Triple, Double Base Systems (TBS or DBS) methods of road construction could be implemented to make costs as low as possible, assuming appropriate specification of bitumen being adopted due to arid desert environment. It was reported that some roads constructed recently suffered severe damages in upper layers. Survey of roads; either south of Libya or in Chad or Niger, (table 2) will be helpful for more assessment. 


\subsection{Rail transport}

At present, there are railway net in Libya or Chad; but there is a project for a $2150 \mathrm{~km}$ long net of railway to be constructed, with $1,435 \mathrm{~mm}$ track gauge to provide an enhanced, secure connection between Libya and African railway net. The use of railway for transhipment of cargo can be implemented at later stages of the development of this project. Double container stacking in rail transport should not be neglected in the study for future development.

\subsubsection{Analysis of transport cost}

The costs of land transport of containers to landlocked countries from West African ports; like Douala in Cameroon or Cotonou in Benin or Lome in Togo are high (tables 3 and 4) and that might be attributed to high prices of fuel. The present average cost of land transport of TEU's from Douala to the oil field camps in south of Chad (Moundou \& Doba) is about 8500 US\$/unit, for a distance of $1100 \mathrm{~km}$ approx. Libyan truck transport costs are nearly half that figure in western African countries (DARDNEEL SHIP AGENCY, 2012). The return journey of containers will get same advantages. The reduction in freight costs normally reflects positively on goods price and its flow and volume. A research on transport investment in 24 African countries performed by the World Bank with technical notes could be of assistance in further analysis. (www.infrastuctureafrica.org).

Table 2. Approx. road distance in kilometres and its condition (LR\&R, 2010)

\begin{tabular}{|c|c|c|c|c|}
\hline Country & From & To & Distance (km) & Description-condition \\
\hline \multirow{3}{*}{ Libya } & Misurata & Sebha & 787 & Highway--good \\
\hline & Sebha & Al Gatroun & 227 & 2-lanes -need maintenance \\
\hline & Al Gatroun & Al Toumm & 318 & 2-lanes-85\% completed \\
\hline \multirow{5}{*}{ Niger } & Al Toumm & Agadez & 1115 & $\begin{array}{l}\text { Construction ceased during } \\
\text { war } 2011, \sim 10 \% \text { completed }\end{array}$ \\
\hline & (Al Toumm) & (Bilma) & 225 & $\begin{array}{l}\text { Constructed partially, works } \\
\text { ceased during war } 2011\end{array}$ \\
\hline & (Bilma) & $\begin{array}{l}\text { (Nguigmi ,on Chad } \\
\text { lake) }\end{array}$ & 450 & $\begin{array}{l}\text { Planned but no Design } \\
\text { Details available }\end{array}$ \\
\hline & Agadez & Niamey & $\sim 900$ & $\begin{array}{l}\text { Under use \&linked to } \\
\text { Uranium High way to Arlit }\end{array}$ \\
\hline & (Agadez) & (Zinder) & $\sim 350$ & $\begin{array}{l}\text { Nearly half paved ,the other } \\
\text { half sand tracks }\end{array}$ \\
\hline Chad & Zinder & $\begin{array}{l}\text { N'Djamena Through } \\
\text { (Diffa-Mao) }\end{array}$ & $\sim 1300$ & $\begin{array}{l}\text { Paved but partially sand } \\
\text { tracks }\end{array}$ \\
\hline
\end{tabular}


Table 3. Inland road transportation costs for FEU (28Tonnes) (UNCTAD, 2009)

\begin{tabular}{lllll}
\hline From & To & Distance $(\mathbf{k m})$ & Total cost $(\$)$ & \$ Cost per $\mathbf{k m}$ \\
\hline Douala Cameroon & N'Djamena Chad & 1,900 & 8,000 & 4.21 \\
Cotonou Benin & Niamey, Niger & 1,056 & 2,200 & 2.08 \\
Lome Togo & Niamey, Niger & 1,234 & 3.160 & 2.56 \\
\hline
\end{tabular}

Table 4. Freight rate from Baltimore (USA) for landlocked countries, 40 Ft container. Source: Maritime Transport Costs and Port Efficiency (WORLD BANK, 2001).

\begin{tabular}{lll}
\hline Destination & Freight (US\$) & Import port \\
\hline Djamena, Chad & 13,000 & Douala, Cameroon \\
Niamey, Niger & 7,000 & Cotonou, Benin \\
Bamako. Mali & 7,000 & Abidjan, cote d'Ivoire \\
\hline
\end{tabular}

\subsubsection{Possible financing resources}

Financing of the new port could be directly from the Libyan government or through loans or investment by major ship liners using the port and interest in this project. Financing of road maintenance and construction of new roads in Chad and Niger could be made through funds and loans from international enterprises like IMF, the World Bank, European and Islamic investment banks. This funds or loans could be based on long term plans.

\section{Conclusion}

The construction of a new additional port in Misurata, should be well linked with the development of north-south net of roads in the territory to be served. To large extent, they are complementary (chained).This issue enables achievement of targeted capacity. Engineering and navigational aspects during the selection process of the best location or layout for the new port should be studied taking into consideration the possible adverse effects on the existing two ports.

Road transport is the major form of transport in Niger \& Chad. Both of these countries are in need for road development, specially, after start of oil export in both of them The cost of land transportation in West African countries is high, due to fuel prices and other reasons. In Libya, containers land transport costs are relatively low due to low fuel prices. Having a corridor for cargo transport to and from the Mediterranean to the landlocked countries through MFZ, looks feasible on a long term strategic basis.

The new port can serve for transhipment (feeder ships) to local and regional ports. A questionnaire survey could be made with major ship liners who are using the port at the present time. Experts in trade and ocean shipping consultants should be involved and consulted for more evaluation. Other competitor regional hubs in the Mediterranean should be investigated. 


\section{Recommendations}

It is worthwhile to revise and up-date the feasibility study of the overall expansion project by MFZ. The two new port schemes (A\&B) should be optimised. Another alternative location; out of the territory between the two existing ports could be considered, south-eastward of the LISCO port. Navigation aspect and free zone compound master plan to be noted. The link between the net of roads (north-south), the future development of the railway and this project should be well considered. Optimisation of containers transport to landlocked countries through MFZ instead of using West African ports is recommended. Energy resources in the region could be of interest in such optimisation and to program the "Energy Corridor of EU with neighbouring countries", due to the growing imbalance between demand and supply of energy. The role of engineering in such project should be evident in order not to over design roads, bridges and railways. Phase's policy of construction could be implemented. Assistance by Technical Assistance and Information Exchange Instrument (TAIEX) experts of the European Commission is recommended for this project, since Libya is one of the sixteen countries recently participating in the European Neighbourhood Policy (ENP).

\section{References}

DARDNEEL SHIP AGENCY (2012). Libyan inland road transport, Tariff 2012.

MFZ -Misurata Free Zone- (web site). http://www.mfzly.com

LR\&R -Libyan Road \& Railway- (2010). Brief report on Strategic Trans Sahara Roads. 72nd Session of the Executive Board.

UNCTAD (2009). Review of Maritime Transport.

WORLD BANK (2001). Maritime Transport Costs and port Efficiency. 